\title{
Do Despotismo da Gentalha à Democracia da Gravata Lavada: História do Conceito de Democracia no Brasil (1770-1870)
}

\section{Christian Edward Cyril Lynch}

Escola de Ciência Política da Universidade Federal do Estado do Rio de Janeiro (UNIRIO) e de Teoria do Estado na Universidade Federal Fluminense (UFF). Rio de Janeiro, RJ, Brasil (e-mail: clynch3@hotmail.com).

\section{INTRODUÇÃO}

\begin{abstract}
A democracia constitui um dos conceitos mais básicos e polissêmicos da política moderna. A partir do momento em que, entre os séculos XVII e XIX, a soberania do povo ou da nação passa a ser vista como o único princípio que legitima a organização das sociedades, a democracia se instaura como o único horizonte possível da política. As divergências todas se resumem, de uma maneira geral, à definição, à conveniência e à oportunidade do seu advento. Do ponto de vista teórico, o contratualismo setecentista já havia estabelecido o seu projeto na forma de uma utopia na qual a sociedade corporativa e hierarquizada do Antigo Regime, legitimada na tradição, fosse substituída por outra, formada pela vontade de indivíduos livres e iguais. Este projeto refletia um processo socioeconômico em curso desde o final da Idade Média europeia e ocidental de nivelamento das condições que erodia os fundamentos estamentais das sociedades europeias ocidentais ("democratização"). Por outro lado, quando das grandes revoluções que marcam o advento da modernidade política, na virada do século XVIII para o XIX, este processo estava longe de ser concluído. Muito menos que todos os países caminhassem no rumo da democracia na mesma velocidade.
\end{abstract}

DADOS - Revista de Ciências Sociais, Rio de Janeiro, vol. 54, n-3, 2011, pp. 355 a 390. 
Estas considerações preliminares servem como um início de reflexão sobre o percurso da própria democracia brasileira. Apesar da abundante literatura, o tema ainda é nebuloso. Uma das principais razões disto se prende ao fato de por muito tempo ter inexistido no Brasil uma correspondência entre os marcos formais de advento do regime liberal democrático e sua prática substantiva. Quando da instauração formal de uma ordem institucionalmente moderna no Brasil, na esteira da revolução de 1821, o processo de "democratização" de sua sociedade estamental tropical ainda era muito incipiente, comparado àquele que tinha curso nos países que haviam liderado as primeiras ondas revolucionárias na América do Norte e na Europa Ocidental (Estados Unidos Inglaterra, França). Neste sentido, inúmeros foram os observadores oitocentistas para os quais a organização política do país era mais sofisticada que seu estado social. Para autores como João Francisco Lisboa, Joaquim Nabuco, Eduardo Prado, Euclides da Cunha, Manuel Bonfim, era o desnível entre o país leal, organizado conforme o cânone político moderno, e o país real, analfabeto, rural, escravista, o responsável pelas disfunções existentes entre a teoria que informava o sistema político-institucional e sua prática: a hipertrofia do poder pessoal do Executivo, as fraudes eleitorais, a falta de partidos ideológicos etc. Esta percepção era basicamente correta - ainda que algumas de suas análises estivessem calcadas num culturalismo exagerado para quem aquelas disfunções resultavam de uma essência imutável da sociedade brasileira, que inviabilizasse a prática do regime democrático (pelo menos tal como se entendia que ele era praticado no mundo anglo-saxão).

Daí que a trajetória da democracia brasileira precisa ser compreendida de uma perspectiva dinâmica de processo que leve em consideração a emergência da classe média e depois das massas no processo político e, neste contexto, compare os marcos político-institucionais às eleições que sob eles tiveram lugar, atentando concomitantemente aos critérios de lisura e de extensão do sufrágio. Por esse ângulo, embora desencadeado enquanto movimento político a partir de 1922, como consequência de melhores níveis de alfabetização e de urbanização, a impressão é que, ao menos do ponto de vista eleitoral e quantitativo, o processo de efetiva democratização da sociedade brasileira começa na verdade em 1945. Ele atravessa o período militar (quando a participação eleitoral dobrou, ainda que tutelada e restrita aos cargos legislativos) para se concluir cerca de quarenta anos depois. Estes fatos contrastam, porém, com a insistência com que parte da literatura, principalmente a de tendência liberal, tenha insistindo em qualificar as elei- 
ções imediatamente posteriores à queda dos nossos regimes autoritários (1985, 1945 e 1933) como expressivas de um processo de "redemocratização". Partem eles da premissa de que, embora interrompida vez por outra, a democracia seria um traço habitual, inerente da tradição política brasileira. Ora, apenas a primeira eleição realizada livre da tutela do governo com uma participação popular superior a $40 \%$ da população aconteceu somente em 1986. A última eleição presidencial anterior ao regime militar, em 1960, contou com uma participação eleitoral que era menos da metade daquela (16\%). A "redemocratização" que se seguiu à queda do Estado Novo é ainda mais digna de ponderação, pois à sua primeira eleição (1945) não acorreram mais que 13\% da população. Comparando-se as taxas de 1945 e de 1960 à de 1986, é mais apropriado falar em "redemocratização", ou simplesmente em "democratização" (Nohlen, 2005)? O paroxismo encontra o seu apogeu quando da "redemocratização" de 1933, promovida na esteira de uma famosa "revolução paulista" feita em seu nome, e a cuja eleição compareceu menos de $4 \%$ da população (Ramos, 1961) ${ }^{1}$.

Essas baixíssimas taxas de participação política nunca impediram, porém, que a maioria dos contemporâneos vislumbrasse cada um daqueles momentos históricos como um momento de "redemocratização". Mas a que "experiência democrática" fundadora aqueles liberais (principalmente os de 1945 e 1933) parecem assim se referir? Por mais estranho que nos pareça hoje, eles se referiam àquela representada pela Primeira República, marcada pela sistemática corrupção eleitoral e de baixíssima participação eleitoral (entre 1\% e 3,5\%). Verdadeira paródia de democracia, tal como hoje a consideramos.

Ora, por que a realidade empírica de ausência de democracia, ou no mínimo de sua insuficiência, não impedia os contemporâneos de considerar a sua realidade como democrática? Algumas respostas podem ser aventadas. Em primeiro lugar, aqueles autores/atores estavam presos a uma concepção radicalmente liberal da democracia. Por "redemocratização", referiam-se ao restabelecimento de direitos e garantias fundamentais tipicamente liberais, como a liberdade de ir e vir, a liberdade de comunicação, de imprensa e de reunião. É certo que o restabelecimento do direito de voto estava aí incluído. Mas esses atores e autores políticos possuíam uma concepção restrita acerca de quem pertencia à nação ou ao povo soberano, fundamento da democracia, ou de quem estava apto a representá-la legitimamente: a porção esclarecida e abastada da população. Essa concepção aristocrática de democra- 
cia, radicada originalmente na concepção senhorial dela formulada pelos setores "avançados" das elites desde a independência, encontrou sua primeira formulação explícita na "democracia da gravata lavada" de Teófilo Otoni, quando de sua famosa campanha do lenço branco, em 1860. Aquele símbolo seria resgatado pelos campeões da "redemocratização" de 1945, os liberais da União Democrática Nacional (UDN), que fizeram do lenço branco o símbolo, talvez involuntário, de seu ideal de uma democracia educada² .

Este artigo intenta descrever o processo pelo qual, prensadas entre uma moldura institucional moderna e uma realidade social análoga à do Antigo Regime, as elites brasileiras do século XIX lentamente elaboraram esse conceito puramente liberal-institucional de democracia, essencialmente federativo, que por tanto tempo persistiria e persiste no imaginário de nossas elites. A metodologia empregada é aquela da história dos conceitos, de Reinhart Koselleck. Como é sabido, Koselleck bebe das categorias heiddegerianas de condições de possibilidade de histórias, contidas no quadro do Dasein, e da hermenêutica filosófica de Gadamer, para quem o conceito seria a principal ferramenta para a inteligibilidade do fenômeno humano. A partir delas, Koselleck criou em projeto historiográfico a descoberta da historicidade intrínseca à experiência humana na modernidade, projeto este dos mais importantes para uma captura adequada das mudanças ocorridas no campo do pensamento político. Além de ter de abordar inevitavelmente um estado extratextual de coisas (Koselleck, 1997:93), o estudioso da história teria a obrigação de situar os conflitos sociais e políticos do passado em suas respectivas fronteiras conceituais, colocando-os em relação com a continuidade ou não das estruturas políticas, econômicas e sociais. Como o conceito ligado a uma palavra é sempre mais do que esta palavra, ambos devem ser adequadamente distintos; além disso, os conceitos não têm conteúdos estáveis; o que permite dizer que a história dos conceitos, na verdade, é a história de suas diferentes recepções no tempo e no espaço (Jasmin e Feres Jr., 2006:25). Correlatas a estas ponderações, para Koselleck há um período particularmente digno de estudo conceitual: aquele por ele denominado Sattelzeit (1750-1850). Por este termo, Koselleck designa o período de transição sofrido pelo sistema político conceitual do Antigo Regime para o constitucionalismo e liberalismo, com um horizonte de expectativas democrático. Acompanhando as transformações socioeconômicas ocorridas na Europa ocidental, os conceitos políticos teriam sofrido durante aquele século quatro grandes processos: a democratização (alargamento do seu cam- 
po de uso por camadas até então alijadas), temporalização (os conceitos passaram o futuro e não mais o passado como referência), ideologização (os conceitos perdem sua dimensão concreta para se tornarem cada vez mais abstratos) e politização (os conceitos passam a adquirir acentuada polissemia por seu emprego por diversos setores na arena política).

No entanto, alguns cuidados preliminares referentes à aplicação dessa metodologia devem aqui preceder a exposição do presente texto, em razão da ausência, na sociedade brasileira da época, de certas condições sociais de caráter estrutural, que parecem, todavia, constituir não-ditos da história conceitual. No ambiente europeu e da Nova Inglaterra, o conceito de liberdade agiu sobre sociedades que, apesar de hierárquicas, eram marcadas por certa homogeneidade cultural e étnica, fosse ela real ou imaginada. Essa homogeneidade era pouco visível no Brasil, onde a mestiçagem dos povos ibéricos com povos autóctones e outros, trazidos de outros continentes, como o africano, conferiram à sociedade uma complexidade que criava novos componentes sobre as hierarquias preexistentes no universo europeu. Por isso, a variável da escravidão negra não pode aqui ser deixada de lado. Do mesmo modo, a conformação da sociedade brasileira era bastante mais atrasada, por assim dizer, que a europeia ocidental, na época em que elas vivenciaram as transformações socioeconômicas no bojo das quais foi gestada a modernidade política conceitual. A impressão que se tem, é de que a passagem do Antigo Regime para o governo constitucional e representativo liberal não veio acompanhada daquelas mesmas mudanças que tinham curso em países como os Estados Unidos, a Inglaterra ou a França. Este fato refletiu significativamente em algumas daquelas características do processo de modernização dos conceitos políticos - em particular no de democratização. Embora o advento do liberalismo tenha estendido a esfera de livre uso dos conceitos políticos, essa extensão se deu de modo muito limitado, constituindo uma esfera pública bastante mais restrita do que aquela existente nos países centrais, e que normalmente excluía, por exemplo, todo o universo de trabalhadores manuais em atividade. É o que aqui justifica também que o período do Sattelzeit seja atrasado em vinte anos, passando a contemplar o período entre 1770 e 1870.

\section{O CONCEITO ANTIGO DE DEMOCRACIA (1770-1792)}

Entre 1770 e 1792 a democracia foi compreendida como uma forma de governo que, a despeito de resistir aqui e ali na forma de cidades-Esta- 
do, possui uma dimensão eminentemente histórica. O Dicionário Bluteau de 1713 a define como "um governo político, diretamente oposto à monarquia, porque é popular, e nele a eleição dos magistrados depende dos sufrágios do povo". Os exemplos são justamente extraídos da Antiguidade: "Nas Repúblicas de Roma e de Atenas floresceu a democracia ou governo democrático". No verbete democrático, o autor do dicionário pôde manifestar mais claramente a sua opinião ao qualificar aquele governo como "monstruoso". E explicava: "É governo vulgar e o vulgo sempre há sido, e com domínio, monstro formidável: tem conselho, tem razão, tem esfera, tem segredo e tem revolução. Todos querem ter cabeças" (Bluteau, 1713).

No Brasil, o estudo da história dos conceitos é particularmente difícil pela proibição de tipografias imposta pelo governo metropolitano até 1808. Entretanto, até onde se verifica por meio dos documentos oficiais das autoridades coloniais, o conceito de democracia não era diferente daquele anotado por Bluteau. Em carta de 1770 ao Conselho Ultramarino, o Marquês do Lavradio, vice-rei do Brasil, revelava seu desgosto com a iniciativa dos "magnatas" da capitania de Goiás que, diante da morte do governador, haviam nomeado um governo interino por conta própria, quando só o rei poderia fazê-lo: "Só o mesmo Senhor é quem pode ceder de si aquele poder que é unicamente seu. De outra forma, seria conceder aos povos aquele poder que já hoje não tem, e por consequência usurpar, aos soberanos, o poder supremo e absoluto que possuem e exercitam entre todos os seus povos naquela capitania" (Lavradio, 1978:31). Dois anos depois, Tomás Antônio Gonzaga exprimia idêntico juízo em seu Tratado de Direito Natural. Seguindo a classificação de Pufendorf, Gonzaga sustentava que os governos se dividiam entre regulares e irregulares. Os regulares teriam o poder político concentrado "à maneira de um corpo que se anima de uma só alma, se regem e governam por uma só cabeça", ao passo em que nos irregulares prevaleceria uma constituição mista, como na Inglaterra. Os governos regulares possuiriam três formas: a monarquia, a aristocracia e a democracia. Se o poder da cidade estivesse "em um conselho formado dos votos de todos", ela se chamava "democracia", e aqueles que a compunham, "povo". Tendo em vista que o bom governo deveria agir com presteza e diligência, a democracia era a pior de todas as formas de governo: até "que se ajunte um povo, se conformem os votos e se decida a coisa, já muitas vezes tem chegado o mal a termos que não tem remédio, à maneira do enfermo que morre? pela indeliberação do médico". A monarquia, por conseguinte, era a melhor forma de governo, porque 
era mais ágil: "Ainda que, do governo de um só, se possam seguir alguns incômodos, os que se podem seguir do governo de muitos são mais e mais nocivos". Detentor do poder soberano, o rei era um "ministro de Deus para o bem"; e não poderia por ele ser removido pelo povo, ainda que eleito por ele, porque já investido do poder de império (Gonzaga, 2004:135-137).

\section{O CONCEITO JACOBINO DE DEMOCRACIA (1792-1831)}

No Dicionário Morais de 1813, a democracia é definida como forma de governo no qual "o sumo império, ou os direitos majestáticos residem atualmente no povo e são por ele exercidos". O referido dicionário registra ainda os verbetes democratismo, qualificado como "o regime democrático, suas instituições, doutrinas, fórmulas e sentimentos próprios dos democratas ou democracias", e democratizar, neologismo que já refletia o processo de independência das antigas colônias europeias: "Dar constituição democrática; ou mudar a constituição em democracia, reduzir a democracia" (Morais e Silva, 1813). Estas são definições que não sofrerão variações, pelo menos até a década de 1870.

O conceito de democracia que prevalece a partir de 1792 é muito negativo. Eram os "abomináveis princípios franceses", invariavelmente republicanos, democráticos e igualitários (Jancso, 1995:141). Em outras palavras, até pelo menos 1830 não havia distinção clara entre os conceitos de democracia e de república, que eram tomados como sinônimos. Aqui, o significado pode ser extraído, mais uma vez, dos documentos oficiais, especialmente pelas devassas instauradas contra os acusados no período do crime de sedição. Os membros da Sociedade Literária do Rio de Janeiro, interditada pelo vice-rei, o Conde de Resende, sustentavam que "o governo das repúblicas deve ser preferido ao das monarquias, e que os reis são uns tiranos opressores dos vassalos" (Martins, 1974:506). Se um deles, Silva Alvarenga, entendia não haver "melhor governo do que o governo de iguais" - com a inevitável salvaguarda "desde que restrito aos iguais" -, outro membro da sociedade, Francisco Antônio considerava que "as leis francesas eram boas pela igualdade que introduziam entre os homens", e que "só quando os franceses cá chegassem se poriam as cousas direitas" (Figueiredo, 2001). Na biblioteca dos acadêmicos foram encontrados livros "perniciosíssimos", entre os quais, os dos abades Mably e Raynal. Depois de 1798, porém, diante de uma tentativa de sedição em Salvador, de que brancos pobres, mulatos e escravos tomaram parte, pregando uma república ni- 
veladora, esmoreceu significativamente o entusiasmo das elites coloniais com a democracia. Os sediciosos se dirigiam ao "poderoso e magnífico povo baiense republicano" e clamavam que, depois da revolução, "todos serão iguais, não haverá diferença, só haverá liberdade, igualdade e fraternidade" (Jancso, 1995:124).

Como sugerira Alvarenga, para a elite colonial, o governo dos iguais deixava de ser bom quando estendido aos desiguais, ou seja, aos pobres ("o povo mecânico"), ou pior ainda, aos escravos. Eis por que, quando a aristocracia pernambucana levantou-se contra Coroa, em 1817, os insurretos só pronunciavam a palavra república "em voz baixa" e só discorriam sobre a doutrina dos direitos do homem "com os iniciados", já que ela "não seria compreendida pela canalha" (Mello, 2004:38-39). Por outro lado, os defensores da monarquia absoluta de Dom João VI equiparavam os frondeurs pernambucanos aos jacobinos franceses de 1792. O redator do periódico governista A Idade d'Ouro no Brasil advertia que, por aquele motivo, a palavra "patriota" se tornara "sinônimo de impostor, perturbador e velhaco. Os patriotas não se lembram do bem público, lembram-se de sua fortuna particular: não têm pena dos vossos males; têm inveja dos vossos bens. São Robespierres e Marats". A Revolução Pernambucana de 1817 não passava, em suma, uma "rebelião de demagogos" (Silva, 1978:159).

\section{O PARTIDO REALISTA OU CONSERVADOR: A MONARQUIA CONSTITUCIONAL COMO GOVERNO MISTO}

Com o final do Antigo Regime e a instalação do processo político ao cabo do qual emergiria o Brasil independente como monarquia constitucional, em 1822 a liberdade de imprensa foi proclamada e o debate público finalmente veio à tona na forma de escritos impressos. O espectro político dividiu-se então basicamente em dois grandes grupos: o deputado Martiniano de Alencar reconheceria a divisão partidária em 1823, no plenário da Constituinte: “De certo tempo para cá o Brasil parece dividido em dois partidos. Todos desejam a independência, porém uns seguem ideias democráticas, e outros, aristocráticas" (AACB, $22 / 7 / 1823)$.

Segundo Sierra y Mariscal e Madeira de Melo, o segundo desses partidos - o realista $a^{3}$ - seria composto pelos "mais poderosos em posses, em empregos de representação ligados aos togados do Rio de Janeiro" (Silva, 1978:181). Pertencente à antiga elite metropolitana, formado em 
sua maioria de graduados na Universidade de Coimbra, ocupava a direita do espectro político. A partir dos escritos de Montesquieu e De Lolme, assim como dos discursos pronunciados pelo partido dos monarquianos [monarchiens] no início da Revolução Francesa - Malouet, Mounier, Clermont-Tonnerre, Lally-Tollendal -, os realistas desejavam instaurar, no âmbito do Reino Unido, uma monarquia constitucional à inglesa. Por tal, compreendiam um governo misto, marcado pelo equilíbrio entre os elementos monárquico (a Coroa), aristocrático (o Senado vitalício) e o democrático (a Câmara dos Deputados). Assim, por exemplo, preocupado com o projeto unicameral que se desenhava nas Cortes de Lisboa, em 1821 o redator do periódico Correio Braziliense, Hipólito José da Costa, defendia em editorial a necessidade de "harmonizar os elementos monárquico e democrático" daquele projeto de Constituição por meio da previsão de uma segunda Câmara legislativa. Ela poderia manter "o justo equilíbrio entre as pretensões de uns e outros, evitando a aceleração na fatura das leis e o demasiado desejo de inovação, que sempre existe mais ou menos em todas as assembleias populares, e contendo os abusos do Executivo" (Costa, 1977). Idêntica preocupação era manifestada no Rio de Janeiro por Januário da Cunha Barbosa e Gonçalves Ledo, redatores do Revérbero Constitucional Fluminense, desde que passaram a apoiar as pretensões do Príncipe Regente, Dom Pedro: “Quando as Cortes fizerem tudo, a forma de governo será puramente democrático-representativa, e então o rei será um elemento desnecessário na Constituição" (Barbosa e Ledo, 1822).

A aspiração dos realistas continuou depois da Independência. Naquele momento de fundação do Império, eles entendiam que somente um rigoroso governo misto representativo poderia assegurar a conciliação da liberdade com a ordem, preservando os direitos individuais e, ao mesmo tempo, a unidade do Brasil. Assim, na Fala do Trono que abriu a Assembleia Constituinte de 1823, o Imperador advertia os deputados que as constituições democráticas ensaiadas na França, em 1791, na Espanha, em 1812, e em Portugal, no ano anterior, eram "teoréticas e inexequíveis". O modelo inglês era o único que, "pondo barreiras inacessíveis ao despotismo, quer real, quer aristocrático, quer democráti$\mathrm{CO}^{\prime}$, poderia "afugentar a anarquia" e plantar "a árvore da liberdade" (AACB, 3/5/1823). Aberta a Constituinte, o deputado José Joaquim Carneiro de Campos, futuro Marquês de Caravelas, explicava o caráter da monarquia que pretendia instaurar: "A monarquia representativa é um governo misto, que se combina umas vezes com elementos democráticos, outras com a aristocracia e democracia juntamente" (idem, 
26/6/1823). Não destoava o deputado Luís José de Carvalho e Melo, futuro Visconde de Cachoeira:

Todo o [sic] governo que se chama constitucional ou representativo é um composto que se ressente mais ou menos dos três governos símplices que se chamam: monárquico, aristocrático e democrático. O governo monárquico-constitucional é igualmente composto do que há de melhor na monarquia e democracia, e os filósofos políticos, que exaltam tanto a sabedoria e vantagens dele, dão por causal o ter-se ajuntado o que há de bom e útil nos governos símplices, afastando o que há de mau ou perigoso à liberdade civil e política do cidadão. No regular as atribuições de cada um dos poderes e formalizar o justo equilíbrio consiste a sabedoria e vantagens desta instituição (idem, 31/10/1823).

Embora se reconhecesse que, para além da democracia pura, havia também a democracia representativa, nenhum dos governistas do reinado de Dom Pedro I qualificava como tal a monarquia constitucional. Para o deputado e ministro da Fazenda Martim Francisco de Andrada, a diferença entre a democracia representativa e a monarquia constitucional estava em que, nesta última, o monarca possuía o direito de veto sobre os projetos de lei encaminhados pelo Parlamento, ou seja, "tal ou qual ingerência no poder legislativo" (idem, 16/5/1823). No mesmo sentido, o deputado Carneiro de Campos apontava que o caráter distintivo das democracias residia na supremacia do Legislativo sobre o Executivo: "Nas democracias [...] o supremo magistrado não pode ser mais do que o agente passivo e executor da verdade imediata do povo" (idem, 26/6/1823). Já o deputado Antônio Carlos de Andrada Machado negava mesmo que houvessem existido governos democráticos: tanto o modelo grego quanto o norte-americano não teriam passado, na verdade, de aristocracias eletivas (idem, 16/5/1823).

No entanto, numa releitura da tradicional teoria de que os reis governavam pela vontade dos povos, expressa no Antigo Regime pela sua aclamação e confirmação pelas Câmaras municipais, os realistas se apropriaram da dimensão cesarista ínsita ao bonapartismo. Eles argumentavam que o Imperador era superior ao Parlamento na medida em que o povo o aclamara, em praça pública, seu Defensor Perpétuo e primeiro representante. De fato, José Bonifácio difundiu então a tese de que, naquela ocasião, a nação delegara ao monarca o exercício do poder soberano indispensável para que ele pudesse velar pelos seus interesses. Daí que, na conformidade da fórmula que antecederia todos os atos imperiais, Dom Pedro era "Imperador Constitucional e Defensor 
Perpétuo do Brasil" pela "graça de Deus", é certo, mas também pela "unânime aclamação dos povos". Essa teoria da origem democrática da autoridade do príncipe seria com frequência invocada contra as veleidades da esquerda liberal de enfraquecer o poder monárquico em benefício da Câmara dos Deputados. Assim, diante da declaração efetuada pelo deputado liberal Teófilo Otoni, em 1841, de que a legitimidade do Imperador dependia exclusivamente da Constituição, o deputado conservador Honório Hermeto Carneiro Leão, futuro Marquês de Paraná, retrucaria certeiro: "Não é exato que a autoridade do Imperador só viesse da Constituição: a Constituição reconheceu um fato preexistente no Brasil, que foi a sua unânime aclamação" (ACD, 9/7/1841). Ainda em 1866, o conservador José de Alencar repetiria em suas Cartas de Erasmo que a aclamação do monarca fizera desprender da nação uma parte de sua soberania, que encarnara assim "em um homem superior, para adverti-la em seus erros, e resistir à veemência de suas paixões". O Poder Moderador, isto é, o poder autônomo do Imperador, representava, pois, "o eu nacional; a consciência ilustrada do povo (Alencar, 1866:53-54).

Para os realistas, a democracia como forma pura, associada à república federal, era o inimigo a ser combatido. Prometendo jamais alistar-se sob "as bandeiras esfarrapadas da suja e caótica democracia", o primeiro-ministro de Dom Pedro I, José Bonifácio de Andrada e Silva, declarava em 1823 pertencer ao partido dos "monárquico-constitucionais", cujos adeptos "fitam suas vistas na felicidade do Estado; não querem democracias nem despotismo; querem liberdade, mas liberdade bem entendida, e com estabilidade" (AACB, 15/07/1823). Por isso ele não concorreria "para a formação de uma Constituição demagógica, mas sim monárquica" (idem, 4/5/1823). A oposição ao seu ministério queria uma monarquia falsa, "na qual o monarca fosse um postulado gratuito e sem força, um verdadeiro fantasma, como o de Portugal", verdadeira máscara de uma "república federal" (Lustosa, 2000:348). Seus membros acusavam o segundo partido - o dos brasilienses - de querer irradiar para o Brasil os "perigos do governo democrático", ameaçando-o "pelo exemplo e contágio dos Estados continentais da América" (Neves, 2003). Os oposicionistas eram, assim, considerados por Bonifácio uma "facção oculta e tenebrosa de furiosos demagogos e anarquistas" (Lustosa, 2000:261). Os democratas eram "iluminados, carbonários, radicais", que "têm desordenado e ensangüentado a Europa e ameaçam o sossego de todos os povos e a estabilidade dos governos" (AACB, 17/05/1823). 
No começo da década de 1820, José da Silva Lisboa, futuro Visconde de Cairu, sustentava que a participação política estava legitimamente circunscrita àqueles que, esclarecidos, compreendessem adequadamente os interesses da nação: "O governo deve atender à opinião pública das classes ilustradas, mas não condescender com a populaça móvel e mutável, agitada por ambiciosos demagogos" (Cairu, 1832:137). Estes últimos tentavam iludir "o vulgo" com seu "catecismo jacobínico", recheado "com falsos dogmas do paradoxista de Genebra" (i.e., Rousseau), "para constituir o povo no mais feroz dos tiranos" e instituir afinal o "despotismo da gentalha" (Lustosa, 2000:193). Ainda em 1854, o senador Almeida e Albuquerque qualificava todos os que ainda se opunham à compreensão da Constituição brasileira como um governo misto à inglesa de "demagogos ou satélites da populaça, embriagados com as ideias de liberdade absoluta e ambiciosos de se constituírem os melhores" (Albuquerque, 1854).

\section{UM REPERTÓRIO ANTIDEMOCRÁTICO: OITO RAZÕES CONTRA A DEMOCRACIA NO BRASIL}

De um modo geral, circularam desde então pelo menos oito argumentos para justificar a impossibilidade de democracia no Brasil. O primeiro deles ecoava a tese de Montesquieu de que as democracias eram próprias de comunidades pequenas quando se tratava de estabelecer no Brasil um dos maiores impérios do mundo. Por isso, o Imperador Dom Pedro I alegava em 1823 que a democracia era "um absurdo neste vasto e grande Império" (Pedro I, 1972). Pelos mesmos motivos, também os redatores do Revérbero Constitucional Fluminense acreditavam que somente a monarquia constitucional facultaria ao país "gozar dos bens da liberdade sem as comoções da democracia e sem as violências da arbitrariedade" (Barbosa e Ledo, 1822).

Extraído da filosofia cíclica da história, o segundo argumento contrário à democracia condenava as formas puras de governo por sua instabilidade crônica. Assim, depois de sustentar que a "igualdade absoluta entre os homens" era "a quimera a mais perigosa de todas na sociedade", o mesmo Revérbero Constitucional Fluminense acenava com o exemplo da França revolucionária, quando a tentativa de se estabelecer uma "república eterna" resultara numa "desenfreada anarquia" e, depois, no "despotismo militar". Os articulistas também lembravam a impossibilidade de se "fazer leis e executá-las democraticamente", na medida em que "a habilidade e superioridade de talentos promoverá 
demagogos, e assim a democracia tenderá sempre à aristocracia e esta à tirania, como se tem observado em todas as idades do mundo" (ibidem). Dez anos depois, já senador do Império, o Marquês de Caravelas combateria a reforma constitucional patrocinada pela esquerda liberal empregando um argumento semelhante:

Ora, Senhores, se tais princípios [democráticos] passam, quem governa o Brasil? A Câmara dos Deputados. Que elemento é este? O democrático. Que governo teremos? O oligárquico. O que se segue dele? A anarquia; e atrás da anarquia, o que vem? O despotismo, porque, depois que os povos vêem correr rios de sangue, procuram um homem que os livre do estado de desgraça a que têm chegado, e que os dirija; e este, aproveitando-se da ocasião, os governa despoticamente, como fez Napoleão. (ASI, 27/06/1832)

O terceiro argumento contrário à democracia residia no caráter anacrônico da democracia. Gonçalves Ledo e Januário da Cunha Barbosa salientavam que, embora "modelos de patriotismo", as democracias não eram mais possíveis no presente, quando "a dissipação, o espírito mercantil, o luxo, a corrupção moral e o egoísmo se têm desenvolvido geralmente". Por isso, a tentativa de instaurar uma democracia só faria "transtornar a ordem das coisas" (Barbosa e Ledo, 1822).

Outro argumento antidemocrático sustentava que, na monarquia constitucional, o elemento que prevalecia era o aristocrático e não o democrático - entendendo-se por "aristocracia" o segmento social destacado por suas virtudes e méritos. Era o que, na Constituinte de 1823, explicava o futuro Caravelas:

Nós não temos aristocracia feudal; não confundamos as acepções desta palavra mágica, os sofismas que se em aqui formado rolam sobre o sentido que se quer dar à palavra aristocracia. A nossa é de mérito, e esta é um elemento indispensável em todas as sociedades; é filha da natureza e fundada na preeminência intelectual e moral. Sem ela, não pode a máquina social ter o seu andamento regular. (AACB, 25/05/1823)

Em 1838, ponderava o deputado Antônio Carlos de Andrada Machado: “Uma nação instruída não é governada senão da forma que ela quer, e, por consequência, a política que segue a câmara é nacional, é a política da parte ilustrada da Nação, não da força bruta, que nunca pesou na balança política, mas da força intelectual. É ela que nos indica a política que quer seguir" (ACD, 18/05/1838). Em 1854, o senador 
Francisco de Paula Cavalcanti de Albuquerque ensinava que a aristocracia era o "governo dos melhores" e, como tal, era "da essência do governo e um elemento de ordem e de progresso". Uma vez que a riqueza territorial e financeira sempre teria influência nos negócios públicos, era melhor organizá-la e legitimá-la para dela tirar os melhores proveitos "morais e intelectuais". Uma aristocracia assim constituída, concluía ele, não repugnaria à democracia nem à monarquia (Albuquerque, 1854).

O quinto argumento antidemocrático residia na oposição entre democracia e governo representativo. Quem na Constituinte mais uma vez esclarecia este aspecto era o deputado Carneiro de Campos, futuro Marquês de Caravelas:

Os novos usos e costumes, que tem trazido a civilização; o aumento das necessidades; o grande trabalho para as satisfazer, apesar da perfeição da indústria; finalmente, o amor do repouso e dos prazeres - tudo isso liga tão estreitamente os homens aos seus negócios particulares, e os encerra tanto no círculo deles, que bem poucos cidadãos podem dispor do tempo preciso para meditar e curar dos negócios do Estado, muito mais fazendo a complicação extrema da arte social, com que a maioria das pessoas da povoação seja inábil para as funções políticas. Nestes termos, esta desistência geral que faz a Nação de por si mesma cuidar dos seus interesses, $\mathrm{d}$ 'onde nasceu o belo e admirável sistema representativo, é obra da necessidade, aconselhada e aprovada pela razão. (AACB, 6/11/1823)

Era sem dúvida o reconhecimento da singularidade da população no Brasil, em virtude da escravidão, do analfabetismo e de sua irregular distribuição pelo território nacional que inviabilizava a democracia como forma de governo. Assim, embora reconhecesse em 1817 que "as aparências de democracia" eram "as que mais lisonjeiam os indivíduos das classes mais numerosas", Hipólito da Costa defendia a monarquia para o Brasil porque "conforme com a educação, modo de vida, religião e costumes daquele país" (Costa, 1977). Tínhamos população, mas não tínhamos povo. Em 1821, o futuro deputado José Severiano Maciel da Costa, Marquês de Queluz, explicava que os escravos eram inimigos potenciais do Estado e impediam a formação da nacionalidade: "No Brasil, por efeito do maldito sistema de trabalho por escravos, a população é composta de maneira que não há uma classe que constitua verdadeiramente o que se chama povo" (Martins, 1974:105). Esta era também a opinião de Carneiro de Campos. A população do Brasil 
era "composta pela maior parte de escravos, inimigos natos, e com toda a razão e justiça, bem como os mesmos libertos, dos homens bran$\cos ^{\prime \prime}$. Caso chegasse ao poder acenando irresponsavelmente com a liberdade e a igualdade gerais, a demagogia poderia desencadear uma insurreição de escravos que inviabilizaria o país, como no Haiti (Resende, 1864:68-69). Para um jornalista pernambucano, a democracia brasileira não passaria de paródia:

Uma república brasileira, proclamando a liberdade e a igualdade, nunca poderia deixar de produzir o contraste burlesco de se ver um pequeno número de homens brancos envoltos em cambraias e tafetás, conduzidos em palanquins ou redes, por pretos de pés descalços, que se compram, vendem, alugam e açoitam liberal e constitucionalmente, como as mulas, machos e cavalos. (Mello, 2004:15-16)

Por esses motivos, somente um governo esclarecido poderia modificar o perfil daquela população e transformá-la num povo. Não poderia haver Império sem um governo que, embebido no espírito do despotismo ilustrado, forjasse o povo brasileiro por um regime tutelar, promovendo o amálgama das etnias, a educação para a liberdade, a civilização dos índios, a imigração estrangeira, a distribuição de terras, a construção de universidades e a extinção do tráfico negreiro. Para tanto, era preciso um governo, não democrático e federalista, mas monárquico e centralizador. O que a oposição pretendia, por trás de sua retórica pretensamente democrática, era instalar, por meio do federalismo, um verdadeiro feudalismo, que permitisse aos grandes fazendeiros do interior melhor oprimirem o povo miúdo que vivia sob a sua dependência. Daí que, para José Bonifácio, o discurso democrático não passava de cortina de fumaça por que a oposição liberal fizesse de cada província "uma pequena república, para serem nelas chefes absolutos, corcundas despóticos" (Andrada e Silva, 2002:181). Em 1862, o Visconde de Uruguai, chefe e intelectual do Partido Conservador, repetiria que, no quadro de uma comunidade política invertebrada, somente um governo unitário poderoso e imparcial poderia preparar a sociedade para a liberdade. Como demonstrava a experiência das repúblicas hispânicas, a tentativa de implantar a democracia a curto prazo só geraria desordem e caudilhismo: "Não sou inimigo da democracia. Tem ela muitas coisas boas, mas é preciso não a exagerar e conservá-la nos seus justos limites; aliás, pode produzir, como tem produzido, grandes males" (Uruguai, 1960:483). Por isso, tanto os coimbrãos como, depois deles, os conservadores descartavam a tese oposicionista de que a democra- 
cia estadunidense pudesse servir de modelo para o Brasil. Era o que já em 1823 verberava Antônio Carlos de Andrada Machado:

A analogia dos Estados Unidos, só a cegos pode impor; é mister dormir ao pino do meio dia e ter os olhos fechados ao clarão meridiano para não ver a diferença de um povo nutrido desde o berço em ideias democráticas, para outro que, criado no seio da monarquia absoluta, não tem a frugalidade, temperança e amor da igualdade, condições insupríveis das formas republicanas. (AACB, 16/05/1823)

O deputado Carneiro de Campos seguia então a mesma opinião:

Não nos iludamos com o exemplo dos Estados Unidos. Nós somos noviços na liberdade, e eles são já veteranos, eles formam uma justa ideia dos limites da liberdade adquirida pelo gozo que por muito tempo dela já tinham, quando se separaram da sua metrópole, e se constituíram independentes. Já então possuíam governos livres e populares, e tal é a soma de luzes, e de virtudes políticas que sustenta o seu governo, que lhe não podem fazer brecha os anarquistas. (AACB, 3/10/1823)

\section{O PARTIDO LIBERAL E O PROJETO DE MONARQUIA DEMOCRÁTICA}

Já o segundo partido, adversário dos coimbrãos, era visto por Sierra y Mariscal e Madeira de Melo, em 1821, como o "partido democrata", que aspirava a uma "independência republicana" e à instauração de "governos provinciais independentes" (Silva, 1978:181). Este partido liberal possuía duas alas: uma, moderada, de grandes proprietários de terras, ligados à escravidão, e, outra, exaltada, ligada a elementos urbanos de média extração. Ambas atacavam a direita realista como uma "facção luso-aristocrática", uma "oligarquia", porque identificada com a antiga elite burocrática metropolitana. Assim, o exaltado Ezequiel Correia dos Santos, redator de A Nova Luz Brasileira, qualificava a "aristocracia" como "a peste da sociedade, por ser sequaz do governo absoluto e do despotismo; é inimiga da liberdade, da igualdade, da justiça e das boas leis sociais; toda ela é desprezadora do povo, para o qual olha com desdém e como para bestas de trabalho ou tropas de escravos" (Basile, 2001:50). Pela vinculação da direita com a magistratura, odiada desde o período colonial pelos setores produtivos, eram frequentes os ataques da esquerda liberal à "preponderância desembargatória", ao "estratagema desembargatório" (Barata, 2008:511). 
Ocorre que, embora críticos da "aristocracia", os liberais mantinham uma relação muito ambígua com a democracia. A maior parte deles, especialmente os moderados, era integrada por grandes fazendeiros e comerciantes, dependentes do tráfico de escravos e do controle social sobre as massas de trabalhadores, escravizados ou livres. Por isso, os liberais não se sentiam confortáveis para defender abertamente a democracia, porque receavam a pretensão niveladora das classes subalternas, em relação às quais eles mesmos figuravam como "aristocratas". Essa foi talvez a principal razão porque, ainda que a pretendessem mais "democrática" do que queriam os realistas, a maioria esmagadora deles preferiu uma composição constitucional com o regime monárquico. Essa posição dos moderados estava exemplarmente consignada e manifestada na carta que enviaram ao Revérbero Constitucional Fluminense pelo "Sacristão de Tambi". Ele não apenas negava o epíteto de "republicano" como afirmava com todas as letras: "Odeio a democracia". No entanto, o missivista se via obrigado a explicar que também não era absolutista nem aristocrático, pois não desejava "a degradação, a vileza, a escravidão do meu país". Ou seja, embora rejeitasse a aristocracia, o sacristão também não estava confortável com a democracia.

Esta era a própria posição de Januário Barbosa e Gonçalves Ledo, que em 1821 se queixavam que "os inimigos da liberdade brasílica" [os realistas] os acusavam de intentar uma "democracia pura", quando só queriam "consolidar o sistema constitucional" (Barbosa e Ledo, 1822). Também era o que esclarecia o futuro moderado, Diogo Antônio Feijó: "Tanto amo o governo monárquico, representativo, como abomino a democracia pura e a aristocracia num país que tem a felicidade de não a possuir". E acrescentava: "Amo mais o governo absoluto de um só que o chamado liberal de muitos, quer sejam democratas, quer sejam aristocratas" (Feijó, 1999:64). O ideal da democracia era postergado para um futuro distante. Quando tomaram o poder, em 1831, o redator do jornal mineiro O Universal, deputado Bernardo Pereira de Vasconcelos, declarou prontamente não desejar "que tão depressa se desse um salto da monarquia para a democracia". Ele rapidamente incorporava o diagnóstico sociológico dos conservadores apeados do poder: "O presente estado da nossa civilização, a massa heterogênea da nossa população, o vasto litoral que ela ocupa não são elementos próprios para manter esse governo [democrático], aliás excelente, quando a virtude tem o seu poderio sobre todos os cidadãos" . Assim, o país ainda 
não estava preparado para "um sistema de governo puramente democrático", isto é, republicano (Silva, 2009, p. 198).

Ou seja, os moderados eram liberais sem ser democratas. As diferenças entre moderados e exaltados estavam principalmente no fato de que os últimos estavam nas cidades, possuíam uma retórica eivada da linguagem republicana clássica, além de acendradamente antilusitanos. Para os exaltados, a democracia era "o regime o mais livre possível" (Caneca, 2001:452), regime este que se realizaria por intermédio do federalismo. Assim, por exemplo, o ícone do radicalismo pernambucano na época da independência, o Frei Caneca, defendia o ideal da "democracia pura" em termos que o aproximavam do liberalismo radical de Sieyès e de De Tracy. Embora em perfeita sintonia com o liberalismo português e com o liberalismo espanhol das décadas de 1810 e 1820, os exaltados brasileiros não iam muito mais longe que os moderados na busca de uma monarquia democrática. Assim, por exemplo, Caneca salientava em 1824 que, embora a "a tendência do Brasil" fosse para "o governo democrático", uma acomodação com a monarquia seria possível desde que ela abraçasse o ideal de um "regime constitucional representativo" adaptado às circunstâncias locais. Para o autor do Tifis Pernambucano, o "império constitucional" era uma modalidade de governo "colocado entre a monarquia e o governo democrático", que reunia "as vantagens de uma e de outra forma, e repulsa para longe os males de ambas. Agrilhoa o despotismo, e estanca os furores do povo indiscreto e volúvel" (ibidem: 502).

Pode-se, pois, concluir que tanto a direita como a esquerda brasileiras, à época da Independência, eram genericamente liberais, tinham mais ou menos reservas em relação à chamada democracia pura (isto é, republicana) e por isso aspiravam a uma monarquia constitucional organizada tendo por norte o ideal de um governo misto. As divergências despontavam, todavia, quando se tratava de discutir o modo como deveria ser compreendida aquela mistura. $\mathrm{O}$ inimigo dos radicais era o projeto constitucional realista, identificado por eles à Carta francesa de Luís XVIII - qualificada pelo baiano Cipriano Barata de "Constituição servil". Para o exaltado redator de A Sentinela da Liberdade, a Carta de 1814 não era uma Constituição, mas "cativeiro disfarçado debaixo de certas formalidades" (Barata, 2008:209). Os exaltados defendiam um arcabouço institucional que associava o federalismo norte-americano, adotado então na Colômbia e no México, ao modelo monárquico das Constituições portuguesa, de 1822, e espanhola, de 1812. O resultado 
seria uma "monarquia democrática" na qual um poder legislativo unicameral todo-poderoso pairaria sobre um conjunto de províncias confederadas praticamente independentes do poder central. "A massa da província só se há de pacificar", assinalava o Frei Caneca, "quando vir que as Cortes soberanas não estabelecem duas câmaras; que não dão ao supremo chefe do poder Executivo veto absoluto; e que ele não tem a iniciativa das leis no Congresso" (Caneca, 2001:141). Já Ezequiel Correia dos Santos, exaltado do Rio de Janeiro e editor de A Nova Luz Brasileira, aspirava a uma "monarquia americana sui generis" - democrática, constitucional, federalista, não hereditária e eletiva (Basile, 2001:35). A esta altura, percebe-se a dissociação parcial operada entre os conceitos de democracia e república - esta entendida somente como "democracia pura", o que admitia a possibilidade de que houvesse modalidades democráticas de monarquia.

\section{O CONCEITO MODERADO DE DEMOCRACIA: UMA DEMOCRACIA SENHORIAL (1831-1868)}

Para sustentarem suas pretensões de fortalecimento do Parlamento e das províncias, os liberais precisavam refutar o argumento realista de que o Brasil carecia de um modelo monárquico unitário forte, tendo em vista as mazelas decorrentes da colonização, da escravatura, da imensidão do território e o estado decaído da população. Para tanto, desenvolveram a tese de que, porque representada por um conjunto altivo de proprietários de índole democrática, a sociedade brasileira não era invertebrada. Eram as "circunstâncias particulares" do Brasil que recomendavam a adoção de instituições análogas à dos Estados Unidos da América, ainda que adaptadas à monarquia. $\mathrm{O}$ Frei Caneca sustentava que, se por um lado "o espírito da Europa" era o "do servilismo e da escravidão", o espírito do brasileiro era o "de independência, de insubordinação e de liberdade extrema" por descender de indígenas e europeus emigrados, avessos ambos a qualquer noção de submissão voluntária (Caneca, 2001:229). Além desse amor à liberdade, inclinavam os brasileiros à democracia "a simplicidade dos seus costumes"; a "falta das classes salientes da nobreza européia, a impotência de seu clero"; "a sua localidade entre governos republicanos", e a aversão aos três séculos de "escravidão" colonial. Concluindo que "ideias velhas não podem reger o mundo novo" (ibidem: 230), justificava a acomodação do novo Império à forma confederativa de Estado, a adoção do unicameralismo e a rejeição do veto absoluto do monarca. Ou seja, do fato de que o Brasil possuía uma sociedade democrática decorria a necessi- 
dade de nele introduzir, se não a democracia pura, na forma de um governo republicano, ao menos uma monarquia democrática, "americana".

Depois da abdicação de Pedro I, quando tomaram o poder e se viram diante do imperativo de coibir os excessos dos exaltados, os moderados rejeitaram a pretensão de uma monarquia aristocrática unitária, mas também os excessos do republicanismo federalista. O principal doutrinário moderado, o deputado Evaristo Ferreira de Veiga, redator da Aurora Fluminense, salientava a necessidade de se guiar pelo "justo meio, condenando, quer as visões do republicanismo, quer os sonhos não menos absurdos da monarquia aristocrática" (Sousa, 1988:176). Nem por isso, interessados em reformar a Constituição, os moderados abriram mão de mobilizar o conceito de democracia enquanto forma de sociedade. A reforma da Constituição era, para o Regente Feijó, medida indispensável para "purificar a monarquia" de suas "antigas fezes", ou seja, dos hábitos aristocráticos do Primeiro Reinado. Somente assim se chegaria à monarquia democrática; que era monárquica, "mas sem baixeza, sem a menor sombra de aviltamento no seu caráter nobre, livre e independente" (ibidem:159). Decorrente da diversidade de condições face à sociedade europeia, o caráter democrático da nação brasileira criava óbices invencíveis às pretensões aristocráticas dos velhos realistas: "Não possuímos no Brasil colossos de riquezas permanentes como na Europa, que por sua poderosa influência, além de absorver grande parte da fortuna pública, impõem silêncio à classe média, dispõem da numerosa indigência, e modificam a mesma ação dos governos" ( Feijó, 1999:135). Por esse motivo, a tentativa de recriar na América a fidalguia era "objeto de riso para o homem sensato, e de estranheza para o rústico". Ao invés de enfraquecer, ela reforçava "o sentimento de igualdade" que sempre existira entre os brasileiros (Feijó, 1999:135). A reforma constitucional de 1834, inspirada no modelo norte-americano, de fato descentralizou o poder em benefício das províncias, fortaleceu a Câmara dos Deputados e enfraqueceu as instituições políticas não-eletivas. Feijó proclamou então que o Brasil se convertera numa democracia monárquica: "Compare-se o nosso governo com o dos Estados Unidos e conhecer-se-á que no essencial são ambos os Estados governados pelo mesmo sistema, e que a maior diferença está no nome e em certas exterioridades de nenhuma importância para a causa pública". E concluía: "De monarquia, só temos o nome" (ibidem: 166-167).

Com o desaparecimento dos liberais exaltados, àquela mesma época, pode-se dizer que vigorou um quase consenso da elite política em tor- 
no do modelo político da monarquia constitucional e representativa durante os trinta anos seguintes. Para conservadores e liberais, o regime resultava de um equilíbrio entre o princípio monárquico, expressivo da ordem, da autoridade, do unitarismo, encarnado pela Coroa, e o princípio democrático, expressivo, por sua vez, do progresso, da liberdade e da descentralização, encarnado pela Câmara dos Deputados. Do ponto de vista partidário, os conservadores encarnariam o princípio monárquico; os liberais, o democrático, resolvendo-se, por um equilíbrio dinâmico, "o problema da aliança entre a ordem e a liberdade" (ACD, 15/05/1844). Na década de 1850, essa concepção do regime receberia a chancela da filosofia da história: em Ação, Reação e Transação, o deputado conservador Justiniano José da Rocha interpretava as vicissitudes da história política do Brasil independente a partir da luta entre o elemento monárquico e o elemento democrático: este teria prevalecido durante a Regência, e aquele, no começo do reinado de Dom Pedro II. Como resolução àquela antítese, o autor defendia uma transação, que poderia ser materializada por um governo de coalizão entre os dois partidos (Rocha, 1956). Quatro anos depois, em Monarquia-Democracia, Justiniano reiterou a concepção de que o regime político brasileiro era constituído por um feliz amálgama de monarquia com democracia. A democracia era a condição natural do Brasil, dada a sua condição americana, naturalmente igualitária, despida de aristocracia, enquanto a monarquia era "um fato preexistente na sociedade brasileira, uma fórmula de governança tradicionalmente perpetuada, e coeva da civilização do país" (Rocha, 1986:127). Era assim o consórcio da democracia com a monarquia que, juntamente com o "vastíssimo território" nacional, com todas as suas riquezas por explorar, servia de "fiança do futuro" do país (Rocha, 1986:122). Essa ideia de síntese entre monarquia e democracia marcou as décadas de 1850 e 1860, dominadas pelos gabinetes moderados da Conciliação e da Liga Progressista. Assim, depois de saudar "a estrela radiante da democracia que se levanta, quando o astro da Idade Média desaparece no ocaso", o jovem Tavares Bastos recuava em 1862 para consagrar a fórmula superadora das antíteses: "Monarquia e democracia, ordem e liberdade, Constituição e paz, são as primeiras inscrições de todas as bandeiras" (Tavares Bastos, 1976:41).

No entanto, é fundamental chamar a atenção para os limites do conceito liberal de democracia no Brasil, circunscrita ao espaço senhorial graças a uma distinção implícita no significado da palavra povo, empregada tanto como populus para se referir à elite, quanto como plebs para de- 
signar as camadas sociais subalternas. Em 1831, o deputado moderado Evaristo da Veiga esclarecia:

Quando dizemos povo, claro está que não falamos da massa ignorante, ou destituída de interesse na ordem social, que os demagogos adulam e de que fazem o objeto de suas especulações; mas sim dos homens pensantes, honestos e que nada tendo a ganhar na anarquia olham para qualquer aparência de menos prezo que se note a respeito da Nação, do seu decoro e prosperidade. (Basile, 2001:53)

É possível detectar a cisão mesmo nos escritos dos liberais exaltados durante a década de 1820. Eles também lutavam contra as qualificações de desordeiros ou niveladores que lhe eram assacadas pelos adversários. Quando um "aristocrata servil" qualificou seu partido como o representante da canalha, em 1824, o exaltado Frei Caneca protestou: "A canalha de qualquer lugar é a parte ínfima do povo, pela sua qualidade, pelas suas ocupações, pelos seus vícios, pela falta de educação honesta". O partido a que Caneca pertencia, ao contrário, era composto de "varões distintos pela sua origem, sua abundância pecuniária, seus talentos, educação, empregos e sentimentos", compondo "a flor da província" (Caneca, 2001:427). O editor do Tifis Pernambucano aproveitava a ocasião para rebater a tese adversária de que prevalecesse o igualitarismo social nas repúblicas: "Nas democracias puras há classes, há distinções nascidas da indústria e propriedade; e como estas classes são da natureza, não podem ser destruídas por nenhuma forma de governo, e nem jamais nestas relações podem os homens ser nivelados". O que Caneca queria das democracias, portanto, não era a igualdade social, mas tão somente o "espírito da república" (ibidem:252). Posição semelhante era a de Cipriano Barata que, embora obcecado em atacar os privilégios e veleidades do "partido aristocrático", jamais empregou o conceito de democracia em toda a sua produção como jornalista. Assumindo apenas nos últimos dias de vida sua condição de republicano, nem assim ele flertaria com o igualitarismo, preferindo resgatar para o Brasil o ideal de uma "aristocracia republicana", formada pela sabedoria, pela virtude e pela propriedade - isto é, pelos "grandes lavradores" e "grandes negociantes". Pareciam-lhe que, refletidas nas diferenças sociais, as diferenças entre os homens eram naturais (Barata, 2008:910).

A situação não se modificou nos vinte anos seguintes - ao contrário: tendo perdido o fôlego depois de 1835, em todas as suas espasmódicas ressurreições ulteriores, os liberais radicais recuaram de suas preocu- 
pações democráticas. Depois de atacar os conservadores como "facção absolutista", em 1842 o exaltado José Antônio Marinho identificava o seu partido sublevado em Minas Gerias com os grandes proprietários e comerciantes da província. Do lado conservador é que estava a "gente sem qualificação, assassinos e ladrões", entre os quais haveria "condenados" e "pretos da Costa d'África". Os "mineiros industriosos" que haviam se levantado contra o absolutismo conservador se viram ameaçados durante a repressão por "nuvens de [negros] nagôs e minas" enviadas contra eles pelo governo imperial (Marinho, 1978). Seis anos depois, o radical Francisco de Sales Torres Homem também tratava de fustigar "a aristocracia achinelada, entretida à fiúza do orçamento, e para cujos brasões hereditários o povo não podia olhar sem rir-se". Entretanto, ao fazer a defesa do caráter democrático das revoluções liberais, na onda das revoluções de 1848, Torres Homem também distinguia entre populus e plebs. As revoluções liberais da década de 1840 haviam contado com "a flor da sociedade brasileira, tudo que as províncias contavam de mais honroso e eminente em ilustração, em moralidade e riqueza". Já as rebeliões regenciais haviam sido promovidas pela "canalha", alimentada pelo "desencadeamento das paixões, dos instintos grosseiros da escória da população; da luta da barbaridade contra os princípios regulares, as conveniências e as necessidades da civilização" (Inhomirim, 1956:82). O conceito de povo era empregado de modo seletivo: caso este se mostrasse ao lado de quem o invocava, ele era "nobre, heróico"; entretanto, se lhe faltasse, era referido como "plebe e canalha" (Melo, 1978:42).

O que se depreende, pois, desses escritores "democratas" é que, na verdade, a rejeição virulenta da antiga sociedade estamental não se fez acompanhar de uma teorização sobre a democracia para além da igualdade perante a lei e o federalismo. Ela era pensada exclusivamente na chave do liberalismo. Mesmo os radicais só viam produtividade numa revolução restrita à esfera política e, como tal, comprometida com a ordem social. A exceção ficou por conta dos insurretos da Revolução Pernambucana de 1849, quando, já a meio caminho da derrota, anunciaram desejar "o voto livre e universal do povo brasileiro" e "o trabalho como garantia de vida para o cidadão brasileiro" (Chacon, 1985:222). Foi uma exceção que confirmou a regra: as reivindicações caíram no vazio.

Ausente do debate durante dez anos, o conceito de democracia voltaria à cena política nas eleições de 1860, marcada pelo retorno dos antigos 
liberais exaltados, agora chamados "históricos", ou de "partido democrático". No entanto, a exaltação desses liberais continuava mais relativa que nunca. Assim, por exemplo, em Os Cortesãos e a Viagem do Imperador, o deputado Landulfo Medrado ainda se limitava a criticar a monarquia brasileira por se cercar da cortesania típica da Europa, quando o ambiente americano recomendaria uma monarquia democrática, despida do poder pessoal do Imperador (Medrado, 1923;). Naquele mesmo ano, o antigo exaltado mineiro Teófilo Otoni, agora chefe dos históricos, publicou uma Circular aos Eleitores de Minas Gerais que foi universalmente considerada o panfleto mais radical surgido naquele tempo. Defensor dos "princípios democráticos", elogioso do parlamentarismo inglês e da república norte-americana, nem por isso Otoni deixava de sublinhar que sempre estigmatizara "os excessos anárquicos aplaudidos pelas folhas democráticas da Corte". O regime com que sonhava era "democracia pacífica, a democracia da classe média, a democracia da gravata lavada, a democracia que com o mesmo asco repele o despotismo das turbas ou a tirania de um só". Era uma democracia "letrada e asseada, a única merecedora do gozo dos direitos políticos da cidadania" (Otoni, 1916). Nem Marinho, em 1842, nem Torres Homem, em 1848, nem Otoni, em 1860, distavam, assim, da posição moderada de 1835, cuja força estava, segundo um de seus chefes, na "santidade" de sua causa: "a propriedade nacional" (Feijó, 1999: 109).

Para além da cisão entre populus e plebs na configuração dos limites da democracia pretendida pelos liberais, havia quem atribuísse os "sentimentos democráticos" da sociedade brasileira justamente ao fato de ser ela escravocrata. Era o que fazia em 1835 o senador e regente do Império, Diogo Antônio Feijó ao atribuir à escravidão o "sentimento de igualdade profundamente arraigado no coração dos brasileiros". Era o escravismo que lhes incutira no espírito um

caráter já de independência e soberania que o observador descobre no homem livre, seja qual for o seu estado, profissão ou fortuna. [...] Quando ele percebe o desprezo ou o ultraje da parte de um rico ou poderoso desenvolve-se imediatamente o sentimento de igualdade; e se ele não profere, concebe ao menos no momento este grande argumento: Não sou seu escravo. (ibidem: 136, ênfases minhas).

Ou seja, a virtude demonstrada na esfera pública pelos cidadãos que compunham o povo brasileiro, segundo Feijó, surgia da opressão por eles exercida na esfera privada contra os escravos de que eram proprietários. Na verdade, os libelos contra a pretensão de Portugal ou do 
"partido luso-aristocrático" de "reduzir os brasileiros à escravidão", publicados pela imprensa liberal, moderada ou exaltada, não os impedia de anunciarem a compra, venda ou fuga de escravos de verdade. Assim, por exemplo, o lema do periódico moderado O Astro de Minas "Mais vale morrer livre do que viver escravo" - não o inibia de publicar anúncios variados que tinham escravos negros por objeto (Silva, 2009:231). Nem se pense que o hábito estivesse restrito à imprensa moderada: na edição de 6 de setembro de 1823 da Sentinela da Liberdade, depois de denunciar a pretensão portuguesa de reduzir os brasileiros à condição de "escravos", Barata anunciava a recompensa oferecida por um senhor de engenho a quem prendesse um "escravo preto crioulo" que lhe fugira dos domínios (Barata, 2008:430 e 437).

\section{A DEMOCRACIA COMO FORMA POLÍTICA: UM CONCEITO ESVAZIADO (1868-1870)}

A quarta e última fase do conceito de democracia no período data justamente dos seus últimos anos. Dois fatores concorrem para a mudança então ocorrida. Em primeiro lugar, a ressurreição do liberalismo francês em meados da década de 1860 e a deflagração do processo de democratização da Inglaterra, depois da reforma eleitoral de 1867, levaram o paradigma democrático a substituir aquele de constituição mista na explicação do governo representativo legítimo. Do ponto de vista da evolução da política brasileira, em 1868 o Imperador substituiu por conservadores os liberais progressistas que governavam desde o começo da década, o que radicalizou a posição dos liberais, que se voltaram novamente contra o "poder pessoal" da Coroa e a centralização política.

Se a democracia política já era desde muito considerada pelos liberais como o estádio final da dilatação das liberdades públicas para o conjunto dos homens adultos livres, a novidade era que, se antes ela parecia relegada a um ideal longínquo, experimentava-se agora o sentimento de aceleração do tempo histórico, ou seja, de proximidade e inexorabilidade do seu advento. Assim, por exemplo, o jovem Tobias Barreto justificava em 1870 sua adesão ao Partido Liberal, alegando que "o verdadeiro solar do liberalismo é a democracia" (Lima, 1962:38). Neste sentido, embora não fosse automática (porque a Inglaterra era um exemplo de monarquia democrática), permanecia forte a associação entre democracia e república. Em 1875, declarava um dos próceres do Partido Liberal, o senador Zacarias de Góis e Vasconcelos: “As monar- 
quias, posto que tendam a desaparecer perante a democracia..." (Vasconcelos, 1979:470). Até nos arraiais conservadores os ventos da mudança poderiam ser sentidos. Em 1866, o deputado José de Alencar ainda clamava, à maneira de Bolingbroke, pela interferência da Coroa para regenerar a constituição mista corrompida pela indiferença do povo e pela hipertrofia do elemento aristocrático (Alencar, 1866). Dois anos depois, porém, ele já aceitava a generalidade da teoria democrática: monarquia e aristocracia designavam apenas "um modo de ser do princípio democrático" (idem, 1868:34).

Ou seja, não se aceitava mais a legitimidade de um governo representativo que não fosse democrático. Mas o que significava democracia? Na literatura política deste último período, o conceito de democracia apresenta principalmente quatro significados. Os dois primeiros eram meras continuidades da década de 1820 e significavam combate à autonomia do poder monárquico e promoção da descentralização política. No primeiro caso, contra o predomínio do poder pessoal, do imperialismo, do absolutismo, os membros do novo Partido Liberal, como Tavares Bastos, incorporaram a posição dos históricos. Passaram a postular a "transformação ou progresso de nossas instituições no sentido democrático" (Tavares Bastos, 1976:14). Mais à esquerda, os radicais exigiam a abolição do Poder Moderador, do Conselho de Estado, do Senado vitalício e da Justiça Administrativa, bastiões da autonomia do poder monárquico (Brasiliense, 1979:33). Para Saldanha Marinho, chegara a hora de executar, contra os excessos do poder pessoal, "o grande princípio de que, no Brasil, o povo governa o povo" (ACD, 17/07 / 1868). Quando resolveram fundar o Partido Republicano, dois anos depois (1870), esses radicais reivindicaram o título de único "partido democrático", numa tentativa de fazer os conceitos de república e democracia passarem por equivalentes. O objetivo evidente desse expediente retórico era o de obrigar todos aqueles que se dissessem avançados ou democratas a abandonarem os compromissos com a monarquia. Daí seguia também o explícito repúdio do paradigma do governo misto, classificada como "uma ficção sem realidade". Para os republicanos chefiados por Quintino Bocaiúva, era utópico "ligar de modo sólido e perdurável dois elementos heterogêneos, dois poderes diversos em sua origem, antinômicos e irreconciliáveis - a monarquia hereditária e a soberania nacional, o poder pela graça de Deus, o poder pela vontade coletiva, livre e soberana, de todos os cidadãos" (Chacon, 1985:251). 
A democracia servia não apenas para rechaçar a autonomia do poder monárquico, mas também para, mais uma vez, exigir a descentralização política em proveito das províncias. Em A Província, o liberal Tavares Bastos anunciava pretender, "como então queriam os patriotas da independência", democratizar nossas instituições; neste sentido, "o sistema federal" era por ele considerado "a base sólida de instituições democráticas" (Tavares Bastos, 1870). A centralização sujeitava os povos a uma espécie de despotismo mais ou menos dissimulado, que afastava o Estado da sociedade; por conseguinte, absolutismo e centralização tornavam-se equivalentes. Também os radicais criticavam a centralização política, prometendo conseguir "sem revolução armada, sob a forma democrática federal, a posição que nos compete no continente americano" (ibidem:8). No ano seguinte, já republicanizados, os radicais chamavam a atenção, em seu manifesto, para o fato de que a geografia do Brasil já se encarregara "de estabelecer o princípio federativo antes ainda da ideia democrática". Ou seja, a vocação do país para a democracia - e, portanto, para a república e para a federação - estava inscrita na sua própria natureza. Não queria dizer outra coisa a fórmula do Manifesto Republicano: "Somos da América e queremos ser americanos" (Chacon, 1985:270).

Conforme referido, porém, não eram novas essas duas primeiras dimensões do conceito de democracia, que buscavam entendê-la, seja como um governo descentralizado, seja como um governo destituído de poder pessoal. Eram significados puramente político-institucionais, sem qualquer pertinência à esfera da cidadania ou da sociedade. Havia, porém, dois significados propriamente novos do conceito que surgiam no final da década de 1860: democracia enquanto forma político-eleitoral e democracia como sociedade igualitária. A primeira implicava estender o direito de voto para além do círculo preexistente de cidadãos; a segunda, a ampliação do círculo de cidadãos na esfera civil pela extinção da escravidão. Em nome de ambas as causas, Tavares Bastos repetia que a sociedade brasileira era democrática: "O sentimento da igualdade domina aqui até com os seus habituais excessos". A diferença é que, agora, aquele caráter democrático justificava uma reforma eleitoral capaz de "avigorar o elemento democrático da Constituição" pela instituição da eleição direta (Tavares Bastos, 1976:144). Também os radicais pediam "o sufrágio direto e generalizado" (Brasiliense, 1979:33). Da mesma forma, a extinção da escravatura também estava inscrita nos principais programas dos liberais entre 1868 e 1870, fossem eles moderados ou radicais. O prócer liberal Nabuco de Araújo 
explicava: "Do falseamento da eleição derivam-se todas as nossas dificuldades políticas, bem como do trabalho escravo todos os nossos atrasos industriais" (Nabuco de Araújo, 1979:44). Os radicais também assinalaram, entre os seus propósitos, aquele de substituir "o trabalho escravo pelo trabalho livre" (Brasiliense, 1979:33).

Todavia, forçoso é reconhecer a incipiência e a ambiguidade com que emergiram aquelas duas novas dimensões da democracia. Ao reivindicarem a reforma eleitoral em nome da democracia, nem os liberais, nem os radicais, nem os republicanos, se comprometeram com o sufrágio universal. Para Tavares Bastos o sufrágio universal era apenas um "belo ideal das antigas democracias, para que tendem as modernas, mas que estava e ainda está distante de nossa pátria, onde a ignorância e o fanatismo por toda a parte disputam o terreno à civilização" (Tavares Bastos, 1976:143). Também os radicais mobilizavam o conceito de democracia em sentido meramente liberal, ao pedirem apenas que o governo fosse "só governo, que distribua justiça, mantenha a ordem, puna o crime, arrecade o imposto, represente o povo; mas não transponha a meta natural, não se substitua à sociedade; que seja a liberdade a luz que o guie nas escabrosidades da administração e da política" (Brasiliense, 1979:38). Embora a generalização do sufrágio constasse de sua plataforma política, o tema não recebeu qualquer ênfase por parte dos radicais. Pior: quando eles se passaram ao republicanismo, o tópico referente à extensão do sufrágio simplesmente desapareceu - como se o repúdio da monarquia já fosse, por si mesmo, prova bastante de radicalismo. Na verdade, a invocação do conceito de democracia a respeito da reforma eleitoral preservava a cisão entre populus e plebs. Ela precisava excluir do direito de voto "as classes mais rudes da população, essas hordas barbarizadas que se desvivem no vício e no crime, e que a falta de estradas e de escolas abandonou inermes ao embrutecedor fanatismo dos bonzos errantes" (Tavares Bastos, 1976:143). Na mesma senda estavam os radicais que, embora pedissem, em seu programa de 1869, "o sufrágio direto e generalizado", não chegavam a admitir a sua universalidade. Se o direito de eleger e de ser eleito deveria ser estendido, por exemplo, aos acatólicos, ele não deveria ser concedido aos escravos libertos. Era o que explicava o senador Silveira da Mota, chefe radical: "O escravo é homem, mas não é cidadão brasileiro, antes a maioria deles é de cidadania portuguesa, porque veio da Costa da África [...]. Sendo eles estrangeiros, como africanos, pelo fato de se libertarem não ficam imediatamente com o direito de cidadão" (ASI, 28/12/1880). 
No que tange, pois, à reforma eleitoral, embora mobilizassem o conceito de democracia, liberais e radicais estavam muito próximos dos conservadores. A exemplo dos adversários, os saquaremas que queriam a reforma, como Belisário de Sousa, também condenavam o sufrágio universal como "instrumento cego e dócil de todos os despotismos, partam da demagogia ou da autocracia". A única diferença é que eles falavam somente em nome do "governo constitucional representativo" (Sousa, 1979:130-131). Não invocavam a "democracia", como faziam os liberais, moderados ou radicais...

No que tange à abolição da escravatura, era ainda maior a debilidade do conceito de democracia. Embora do Partido Liberal incluísse a progressiva emancipação dos escravos em seu programa de 1869, muitos de seus membros se opuseram ao projeto de lei do ventre livre apresentado pelo gabinete conservador do Visconde do Rio Branco, alegando que se tratava de uma imposição da Coroa. Como se percebe, a abolição era, para a maioria do partido, um tópico secundário: a prioridade era criticar o "poder pessoal" que o alijara do poder. Além disso, na medida em que o Brasil era o último país independente e cristão a praticar o escravismo, a extinção desse regime se prendia menos ao problema da democracia do que à do imperativo de civilizar o país, ou de melhorar a sua imagem internacional (Nabuco de Araújo, 1979:49). A situação não era melhor do lado dos radicais: embora "a substituição do trabalho servil pelo trabalho livre" figurasse no programa do partido, o tópico não foi abordado em nenhuma das conferências públicas por eles organizadas. Além de veicularem anúncios de escravos em seus periódicos (Carvalho, 2007:34), os radicais também se indispuseram com o projeto de liberdade do ventre escravo apresentado pelo gabinete conservador. Durante uma discussão sobre a Comuna de Paris, em 1871, Silveira da Mota aproveitou para atacar o gabinete Rio Bran$\mathrm{co}$, alegando que o projeto do ventre livre "estava fazendo ao país mais efeito e causando mais perturbação que os sucessos de Paris. É desta comuna que eu estou com medo; será uma comuna negra" (ASI, 26/06/1871). Quanto aos republicanos, sequer mencionaram o assunto em seu manifesto. Limitaram-se depois a atacar o projeto Rio Branco em termos politicamente libertários, mas socialmente conservadores: "Assalto à fortuna particular, negação do direito de propriedade, ruína da fortuna pública, perigos de luta de castas, tudo sombrio e de tenebrosos efeitos - tudo em nome do Imperador, como última expressão de sua vontade inelutável". A cisão entre populus e plebs reaparecia no artigo e Vox Populi era o pseudônimo do seu autor (Gerson, 1975:195). 
Isto sem falar na prioridade das reformas político-institucionais sobre aquelas de cunho cívico ou social.

Como se percebe, o que prevalece no período é uma definição negativa, esvaziada ou a contrario da democracia. Ela não é definida como um regime radicalmente novo de ampla participação política, mas como a continuidade do presente, suprimidos apenas o poder pessoal do monarca e a descentralização política. Compreende-se, igualmente, a persistência, no período posterior, de um sentido senhorial e inigualitário de democracia, democracia esta que, por definição, se aproximava da oligarquia de tal sorte que tornava possível confundir um regime com o outro, dando origem à possibilidade futura de uma instauração de uma democracia aristocrática ou oligárquica.

\section{CONCLUSÃO}

O exame das representações do conceito de democracia no Brasil, entre 1770 e 1870, denota, antes de mais nada, a dificuldade de se compreendê-lo para além de um estádio final de liberalização da sociedade, que poderia dispensar ou neutralizar o elemento monárquico e a centralização que o amparava. Porque a parcela liberal da elite da época se representava como socialmente democrática, ou seja, despida do gosto pela hierarquia no interior do seu espaço social, as referências à democracia nunca diziam respeito à participação política ou à questão da escravidão, que implicavam que ela fosse pensada para além do espaço senhorial (cerca de $2 \%$ da população do país). A sua dimensão igualitária só era mobilizada para atacar as instituições que ela não era ainda capaz de controlar, como o "privilégio monárquico" ou da "centralização". Eis porque a representação da sociedade brasileira como democrática só fazia sentido para a elite na medida em que reservava para si as referências positivas de povo ou de nação enquanto populus. Por conseguinte, o significado de democracia acabou apreendido pela opinião pública da época menos pelo seu conteúdo intrínseco do que por oposição à centralização e ao poder pessoal do monarca. Diante da incapacidade de se figurar concretamente o povo soberano enquanto sujeito da democracia, foram "as províncias", genericamente referidas, que assumiram o lugar dele: a vontade da nação passou a significar a vontade das provincias, ou melhor, de suas elites. Neste sentido, o livro "democrático" de Tavares Bastos publicado em 1870 - A Província - é emblemático. Mobilizado retoricamente como regime da participação política do povo soberano, na prática o conceito de democracia significava basi- 
camente autogoverno das elites provinciais sem interferência, fosse da plebe, fosse do governo nacional. Compreende-se, destarte, o caráter fortemente oligárquico da Primeira República, cujo federalismo centrífugo consumiu e absorveu em si o tímido ideal "democrático" longamente gestado pelas elites provinciais sob a monarquia unitária.

Esta concepção de matriz puramente liberal de democracia, restritiva e elitista ("da gravata lavada"), perduraria no decorrer do século XX, encontrando seu arquétipo no conceito que dela faziam alguns dos quadros mais representativos do principal partido liberal brasileiro durante a Terceira República brasileira: a União Democrática Nacional. De fato, nas obras político-historiográficas de Afonso Arinos de Melo Franco, como Um Estadista da República, a Primeira República emerge como um período de ouro da evolução democrática brasileira, evolução que havia sido impedida ou sabotada, todavia, pela manipulação autoritária e demagógica das massas promovida por Vargas a partir de 1930. Por isso, ele lamentava que espetáculos cívico-pedagógicos como aquele comandado por Rui Barbosa (outro ícone do udenismo), durante a campanha presidencial de 1909-1910 - a Campanha Civilista - jamais voltariam a se repetir no Brasil:

Provavelmente, nunca mais o país oferecerá e assistirá a espetáculo semelhante. O nosso tempo pode formar novos titãs. Mas a infeliz contingência dos problemas materiais, que são os que hoje interessam às massas, faz com que os novos condutores sejam, de fato, conduzidos. O poder das elites desapareceu, e os líderes são os que subalternizam seus pensamentos e sentimentos, pondo-o ao nível da trivialidade dos que aparentam liderar. (Melo Franco, 1955, II:612)

Do ponto de vista da literatura liberal, a persistência dessa tradição de pensar a democracia numa dimensão aristocrática tem dificultado a compreensão intelectual do nosso percurso democrático, que deve ser pensado também a partir de sua dimensão social e igualitária, de que ela é inseparável.

(Recebido para publicação em março de 2011) (Versão definitiva em dezembro de 2011) 


\section{Christian Edward Cyril Lynch}

\section{NOTAS}

1. Este questionamento sobre o percurso democrático brasileiro, inclusive sobre o próprio caráter democrático do período entre 1946-1964, encontra-se difuso nas últimas obras de Wanderley Guilherme dos Santos (1994a; 1994b; 2006).

2. Em seus programas e manifestos, a UDN reivindicava abertamente a sua condição de legatária da tradição liberal brasileira que teria surgido com a abdicação de Pedro I, referindo-se constantemente a figuras como Otoni, Tavares Bastos, Rui Barbosa, Prudente de Morais e Assis Brasil. Segundo Maria Victoria Benevides, o lenço branco da campanha de Otoni pela "democracia da gravata lavada", empregada na campanha do brigadeiro Eduardo Gomes à presidência, em 1945, "incorporou-se à linguagem simbólica da UDN" (Benevides, 1985:244-245). O saudosismo da Primeira República é patente nas principais obras de Afonso Arinos de Melo Franco, deputado udenista, filho de Afrânio de Melo Franco e contraparente de Rodrigues Alves, a quem dedicou suas obras de cunho histórico-biográfico: Um Estadista da República: Afrânio de Melo Franco e seu Tempo (1955), e Rodrigues Alves: Apogeu e Declínio do Presidencialismo (1973).

3. Haja vista sua formação universitária e a experiência de socialização profissional comum na burocracia do Império Luso-Brasileiro; historiadores como José Murilo de Carvalho e Lúcia Bastos os chamam "coimbrãos" ou "elite coimbrã". Para evitar, porém, referir-me a eles por meio de uma designação acadêmica, preferi denominá-los realistas, termo então empregado na política europeia para designar genericamente o partido que ocupava a direita do espectro político. É pelo mesmo motivo que me refiro ao grupo à esquerda, denominado por Lúcia Bastos como "brasiliense" ou "elite brasiliense" como liberal, que era como seus membros se intitulavam, para além de designações mais estratégicas: "partido brasileiro", "partido patriota". Limito-me aqui a seguir o exemplo de Armitage em sua História do Brasil, praticamente contemporânea àqueles acontecimentos. Esta opção terminológica não importa, naturalmente, desconsiderar a caracterização que de ambos os grupos ou elites fazem aqueles dois historiadores. Ao contrário, faz-se a ela, aqui, abundante recurso. 


\section{REFERÊNCIAS BIBLIOGRÁFICAS}

ALBUQUERQUE, Francisco de Paula de Almeida e. (1854), Breves Reflexões Retrospectivas, Políticas, Morais e Sociais sobre o Império do Brasil e suas Relações com Outras Nações. Paris, Tipografia de W. Remquet \& Cia.

ALENCAR, José de. (1866), Cartas de Erasmo. Rio de Janeiro, Tipografia Nacional. (1868), O Sistema Representativo. Rio de Janeiro, Garnier.

ANAIS da Assembléia Constituinte Brasileira (AACB), 1823.

ANAIS da Câmara dos Deputados do Império do Brasil (ACD), 1841, 1868.

ANAIS do Senado do Império do Brasil (ASI), 1832.

ANDRADA E SILVA, José Bonifácio de. (2002), José Bonifácio de Andrada e Silva. Organização de textos e introdução de Jorge Caldeira. São Paulo, Editora 34.

BARATA, Cipriano. (2008), Sentinela da Liberdade e Outros Escritos. Organização e edição de Marco Morel. São Paulo, Edusp.

BARBOSA, Januário da Cunha; LEDO, Gonçalves. (1822), Revérbero Constitucional Fluminense, Escrito por Dois Brasileiros Amigos da Nação e da Pátria. Rio de Janeiro, Tipografia Nacional.

BASILE, Marcello Otávio. (2001), Ezequiel Corrêa dos Santos: um Jacobino na Corte Imperial. Rio de Janeiro, FGV.

BENEVIDES, Maria Victoria de Mesquita. (1985), A UDN e o Udenismo: Ambiguidades do Liberalismo Brasileiro (1945-1965). Rio de Janeiro, Paz e Terra.

BLUTEAU, Rafael. (1713), Vocabulário Português e Latino. Coimbra, Real Colégio das Artes da Companhia de Jesus.

BRASILIENSE, Américo. (1979), O Programa dos Partidos e o Segundo Império. Rio de Janeiro, Fundação Casa de Rui Barbosa.

CAIRU, José da Silva Lisboa, Visconde de. (1832). Manual de Política Ortodoxa. Rio de Janeiro, Tipografia Nacional.

CANECA, Frei Joaquim do Amor Divino. (2001), Frei Joaquim do Amor Divino Caneca. Organização e introdução de Evaldo Cabral de Mello. São Paulo, Editora 34.

CARVALHO, José Murilo de. (2007), “As Conferências Radicais do Rio de Janeiro: Novo Espaço de Debate", in J. M. de Carvalho (org.), Nação e Cidadania no Império: Novos Horizontes. Rio de Janeiro, Civilização Brasileira, pp. 17-41.

CHACON, Vamireh. (1985), História dos Partidos Brasileiros: Discurso e Prática dos seus Programas. 2a ed. Brasília, UnB.

COSTA, Hipólito José. (1977), Antologia do Correio Braziliense. Organização e seleção de Barbosa Lima Sobrinho. Rio de Janeiro, Editora Cátedra.

FEIJÓ, Diogo Antônio. (1999), Diogo Antônio Feijó. Organização, introdução e notas de Jorge Caldeira. São Paulo, Editora 34.

FIGUEIREDO, Luciano Raposo de Almeida. (2001), “O Império em Apuros: Notas para o Estudo das Alterações Ultramarinas e das Práticas Políticas no Império Colonial Por- 


\section{Christian Edward Cyril Lynch}

tuguês Séculos XVII e XVIII", in J. F. Furtado (org.), Diálogos Oceânicos. Belo Horizonte, Editora UFMG, pp. 320-354.

GERSON, Brasil. (1975), A Escravidão no Império. Rio de Janeiro, Pallas.

GONZAGA, Tomás Antônio. (2004), Tratado de Direito Natural. Organização e apresentação de Keila Grinberg. São Paulo, Martins Fontes.

INHOMIRIM, Francisco Sales Torres Homem, Visconde de. (1956), “O Libelo do Povo", in R. Magalhães Jr., Três Panfletários do Segundo Reinado. Edição ilustrada. São Paulo, Companhia Editora Nacional, pp. 47-126.

JANCSO, István. (1995), Na Bahia Contra o Império: História do Ensaio de Sedição de 1798. São Paulo, Hucitec.

JASMIN, Marcelo Gantus e FERES JR., João. (2006), “História dos Conceitos: Dois Momentos de um Encontro Intelectual", in M. G. Jasmin e J. Feres Jr., (orgs), História dos Conceitos: Debates e Perspectivas. Rio de Janeiro, Editora PUC-Rio: Edições Loyola: IUPERJ, pp. 27-64.

KOSELLECK, Reinhart. (1997), Historia y Hermenéutica. Introdução de José Luis Villacañas e Faustino Oncina. Barcelona, Ediciones Paidós/I. C. E. de la Universidad Autonoma de Barcelona.

LAVRADIO, Dom Luís de Almeida Portugal, Marquês do. (1978), Cartas do Rio de Janeiro. Rio de Janeiro, Instituto Estadual do Livro.

LIMA, Hermes. (1962), Tobias Barreto: A Época e o Homem. Rio de Janeiro, Ministério da Educação e Cultura.

LUSTOSA, Isabel. (2000), Insultos Impressos: A Guerra dos Jornalistas na Independência 1821-1823. São Paulo, Companhia das Letras.

MARINHO, José Antônio. (1978), História da Revolução de 1842. Brasília, UnB.

MARTINS, Wilson. (1974), História da Inteligência Brasileira. São Paulo, Cultrix.

MEDRADO, Landulfo (1923). Os Cortesãos e a Viagem do Imperador: ensaio político sobre a situação. 4a. ed. Bahia, Imprensa Oficial.

MELO, Urbano Sabino Pessoa de. (1978), Apreciação da Revolta Praieira em Pernambuco. Prefácio de Costa Porto. Brasília, Senado Federal.

MELO FRANCO, Afonso Arinos. (1955), Um Estadista da República: Afrânio de Melo Franco e seu Tempo. Volume II. Fase Nacional. Rio de Janeiro, José Olímpio.

MELLO, Evaldo Cabral de. (2004), A Outra Independência: O Federalismo Pernambucano de 1817 a 1824. São Paulo, Editora 34.

MORAIS E SILVA, Antônio. (1813), Dicionário da Língua Portuguesa, Recopilado dos Vocabulários Impressos Até Agora, e Nesta Segunda Edição Novamente Emendado, e Muito Acrescentado. Lisboa, Tipografia Lacerdina.

NABUCO DE ARAÚJO, José Tomás. (1979), O Centro Liberal. Introdução de Vamireh Chacon. Brasília, Senado Federal.

NEVES, Lúcia Maria Bastos Pereira das. (1998), Corcundas e Constitucionais: A Cultura Política da Independência (1820-1822). Rio de Janeiro, Revan. 
NOHLEN, Dieter (ed.). (2005), Elections in the Americas. A Data Handbook. Vol II. Oxford, Oxford University Press.

OTONI, Teófilo. (1916), "Circular aos Eleitores de Minas Gerais", in B. Magalhães, $A$ "Circular" de Teófilo Otoni. Separata do Tomo LXXVIII, parte 2a, da Revista do Instituto Histórico e Geográfico Brasileiro (IHGB). Rio de Janeiro, Imprensa Nacional.

PEDRO I, Dom. (1972), Proclamações, Cartas, Artigos. Rio de Janeiro, Imprensa Nacional.

RAMOS, Alberto Guerreiro. (1961), A Crise do Poder no Brasil: Problemas da Revolução Nacional Brasileira. Rio de Janeiro: Zahar.

RESENDE, Marquês de. (1864), Memória Histórica de D. Fr. Francisco de S. Luís Saraiva. Lisboa, Academia Real de Ciências.

ROCHA, José Justiniano da. (1956), “Ação, Reação e Transação”, in R. Magalhães Jr., Três Panfletários do Segundo Reinado. São Paulo, Companhia Editora Nacional, pp. 163-218.

SANTOS, Wanderley Guilherme. (1994a), Regresso: máscaras institucionais do liberalismo oligárquico. Rio de Janeiro, Opera Nostra.

. (1994b), Razões da Desordem. 3a ed. Rio de Janeiro: Rocco.

. (2006), Horizonte do Desejo: Instabilidade, Fracasso Coletivo e Inércia Social. 2a ed. Rio de Janeiro, FGV.

SILVA, Maria Beatriz Nizza da. (1978), A Primeira Gazeta da Bahia: Idade d'Ouro no Brasil. São Paulo, Cultrix.

SOUSA, Francisco Belisário Soares de. (1979), O Sistema Eleitoral no Império. Brasília, Senado Federal.

SOUSA, Otávio Tarquínio de. (1988), Evaristo da Veiga. Belo Horizonte, Itatiaia.

TAVARES BASTOS, Aureliano Cândido. (1976), Os Males do Presente e as Esperanças do Futuro. 2a ed. Rio de Janeiro, Companhia Editora Nacional.

. (1870), A Província. Rio de Janeiro, Garnier.

URUGUAI, Paulino José Soares de Sousa, Visconde de. (1960), Ensaio sobre o Direito Administrativo. 2a ed. Rio de Janeiro, Ministério da Justiça.

VASCONCELOS, Zacarias de Góis e. (1979), Discursos Parlamentares. Seleção e introdução de Alberto Venâncio Filho. Brasília, Câmara dos Deputados, p. 470. 


\section{ABSTRACT}

From Riffraff Despotism to Starched Collar Democracy: A History of the Concept of Democracy in Brazil (1770-1870)

The voting rate in Brazil only reached $40 \%$ (considered consistent with a modern democracy) in the 1980s. However, the bibliography always refers to the 1986, 1945, and 1933 elections as moments of "re-democratization", when explicitly or implicitly the original "democracy" could only have existed during the fraudulent and oligarchic First Republic (1889-1930). This article focuses on the process by which the $19^{\text {th }}$ century Brazilian elites slowly forged this purely liberal-institutional concept of democracy, with extensive repercussions during the following century. The concept found its symbol in the "starched collar democracy" to which Teófilo Ottoni referred in his campaign in 1860, limited to the educated and moneyed stratum of the population, and reclaimed by the UDN party in the 1945 presidential campaign.

Key words: history of concepts, democracy, Brazil, $19^{\text {th }}$ century 